\title{
Abrogation of Autoimmune Diabetes in Nonobese Diabetic Mice and Protection against Effector Lymphocytes by Transgenic Paracrine TGF- $\beta 1$
}

\author{
Maki Moritani, ${ }^{\star}$ Katsuhiko Yoshimoto, ${ }^{\star}$ Susan F. Wong, ${ }^{\ddagger}$ Chisato Tanaka, ${ }^{\star}$ Takashi Yamaoka, ${ }^{\star}$ Toshiaki Sano, ${ }^{\S}$ \\ Yoshinori Komagata, $\|$ Jun-Ichi Miyazaki," Hitoshi Kikutani, ${ }^{\star \star}$ and Mitsuo Itakura ${ }^{\star \neq}$ \\ *Otsuka Department of Clinical and Molecular Nutrition, School of Medicine, The University of Tokushima, Tokushima, Japan; ${ }^{\ddagger}$ Section \\ of Immunobiology, Yale University School of Medicine, New Haven, Connecticut 06520; ${ }^{\S}$ Department of Pathology, School of Medicine, \\ The University of Tokushima, Tokushima, Japan; "Institute of Development, Aging and Cancer, Tohoku University, Sendai, Japan; \\ "Department of Nutrition and Physiological Chemistry, Osaka University, Osaka, Japan; and **Department of Molecular Immunology, \\ Research Institute for Microbial Diseases, Osaka University, Osaka, Japan; ${ }^{\ddagger}$ Division of Genetic Information, Institute for Genome \\ Research, The University of Tokushima, Tokushima, Japan
}

\begin{abstract}
Paracrine effect of transforming growth factor- $\beta 1$ (TGF- $\beta 1$ ) on autoimmune insulitis and diabetes was studied by transgenic production of the active form of porcine TGF- $\beta 1$ (pTGF- $\beta 1$ ) in pancreatic islet (islet) $\alpha$ cells in nonobese diabetic (NOD) mice under the control of rat glucagon promoter (RGP) (NOD-RGP-TGF- $\beta 1$ ). None of 27 NOD-RGP-TGF$\beta 1$ mice developed diabetes by $45 \mathrm{wk}$ of age, in contrast to 40 and $71 \%$ in male and female nontransgenic mice, respectively. None of the NOD-RGP-TGF- $\beta 1$ mice developed diabetes after cyclophosphamide (CY) administration. Adoptive transfer of splenocytes of NOD-RGP-TGF- $\beta 1$ mice to neonatal NOD mice did not transfer diabetes after $\mathrm{CY}$ administration. Adoptive transfer of three types of diabetogenic lymphocytes to NOD-RGP-TGF- $\beta 1$ and nontransgenic mice after CY administration led to the lower incidence of diabetes in NOD-RGP-TGF- $\beta 1$ mice versus that in nontransgenic mice: 29 vs. $77 \%$ for diabetogenic splenocytes, 25 vs. $75 \%$ for islet $\beta$ cell-specific Th1 clone cells, and 0 vs. $50 \%$ for islet $\beta$ cell-specific $\mathrm{CD}^{+}$clone cells, respectively. Based on these, it is concluded that autoimmune diabetes in NOD mice is not a systemic disease and it can be completely prevented by the paracrine TGF- $\beta 1$ in the islet compartment through protection against $\mathrm{CD}^{+}$and $\mathrm{CD}^{+}$effector lymphocytes. (J. Clin. Invest. 1998. 102:499-506.) Key words: nonobese diabetic (NOD) mice - pancreatic islets • rat glucagon promoter $(\mathrm{RGP}) \cdot$ adoptive transfer $\cdot \mathrm{CD}^{+}$ and $\mathrm{CD8}^{+} \mathrm{T}$ cells
\end{abstract}

\section{Introduction}

Autoimmune insulitis and diabetes in nonobese diabetic (NOD) ${ }^{1}$ mice $(1,2)$ are regulated not only by helper T lymphocytes $\left(\mathrm{CD}^{+}, \mathrm{Th}\right)$ including $\mathrm{Th} 1$ and $\mathrm{Th} 2$, and cytotoxic $\mathrm{T}$

\footnotetext{
Address correspondence to Mitsuo Itakura, M.D., Ph.D., Otsuka Department of Clinical and Molecular Nutrition, School of Medicine, The University of Tokushima, 3-18-15, Kuramoto-cho, Tokushimacity, Tokushima, 770 Japan. Phone: 81-886-33-7097; FAX: 81-886-319476; E-mail: itakura@nutr.med.tokushima-u.ac.jp

Received for publication 3 February 1998 and accepted in revised form 28 May 1998.
}

J. Clin. Invest.

(C) The American Society for Clinical Investigation, Inc. 0021-9738/98/08/0499/08 \$2.00

Volume 102, Number 3, August 1998, 499-506

http://www.jci.org
$\left(\mathrm{CD}^{+}\right)$lymphocytes, but also by cytokines including IFN- $\gamma$, IL-2, - $4,-10,-12$, and TGF- $\beta 1$ (1). TGF- $\beta 1$, which does not belong to either Th1 or Th2 cytokines, inhibits proliferation of all T cell subsets (3) and B lymphocytes (4), and it suppresses natural killer cell activity (5) and IFN- $\gamma$ and $-\alpha$ production $(6,7)$. Multiorgan inflammation with excessive lymphocytic infiltration in TGF- $\beta 1$ null mice proved the antiinflammatory nature of TGF- $\beta 1(8,9)$. TGF- $\beta 1$ mRNA appears just before the natural remission of Th1-mediated experimental autoimmune neuritis (10), and experimental autoimmune encephalitis (EAE) is prevented by the systemic administration of TGF- $\beta 1(11,12)$ and aggravated by TGF- $\beta 1$ antibody (13). Regulatory CD $4^{+}$ Th3 cells (14) or regulatory $\mathrm{CD}^{+}$cells (15) which dominantly secrete TGF- $\beta 1$ mediate the oral tolerance by the low dose myelin basic protein and proteolipid protein for $\operatorname{EAE}(16,17)$ or insulin for lymphocytic choriomeningitis virus (LCMV)induced autoimmune insulitis and diabetes (18).

Although transgenic (Tg) expression of IL-4 in pancreatic islet (islet) $\beta$ cells (19) suppressed autoimmune insulitis and completely abrogated diabetes in NOD mice, islet $\beta$ cell transgenics for porcine TGF- $\beta 1$ (pTGF- $\beta 1$ ) had chronic exocrine pancreatitis, accumulation of extracellular matrix, and disorganization of islets $(20,21)$. TGF- $\beta 1$ in islet $\beta$ cell double transgenics for pTGF- $\beta 1$ and LCMV GP protein did not protect these mice from LCMV-induced autoimmune insulitis and diabetes (22). Thus, it is not known whether autoimmune insulitis and diabetes in NOD mice can be prevented by the Tg expression of TGF- $\beta 1$. To understand the immunosuppressive role of Tg paracrine TGF- $\beta 1$ for autoimmune diabetes in NOD mice, we produced NOD-RGP-TGF- $\beta 1$ mice in which the active form $\mathrm{pTGF}-\beta 1$ with the potent immunosuppressive activities on murine cells (23) was expressed in islet $\alpha$ cells without directly manipulating islet $\beta$ cells. We report complete abrogation of diabetes in NOD-RGP-TGF- $\beta 1$ mice and protection by the Tg paracrine TGF- $\beta 1$ against adoptively transferred diabetes by effector lymphocytes including diabetogenic splenocytes, islet $\beta$ cell-specific CD $4^{+}$Th1, and $\mathrm{CD}^{+}$clone cells.

\section{Methods}

Production of NOD-RGP-TGF- $\beta 1$ mice. The replacement with mutagenesis of cysteine at 223 and 225 in the latent TGF- $\beta 1$ with serine

1. Abbreviations used in this paper: $\mathrm{BG}$, blood glucose; $\mathrm{CD} 8^{+}$, cytotoxic T; CY, cyclophosphamide; EAE, experimental autoimmune encephalitis; islet, pancreatic islet; LCMV, lymphocytic choriomeningitis virus; mTGF- $\beta 1$, murine TGF- $\beta 1$; NOD, nonobese diabetic; NOD-RGP-TGF- $\beta 1$, transgenic NOD mice in which pTGF- $\beta 1$ was expressed in islet $\alpha$ cells; pTGF- $\beta 1$, the active form of porcine TGF$\beta 1 ; \mathrm{Tg}$, transgenic; Th, $\mathrm{CD} 4^{+}$helper $\mathrm{T}$. 


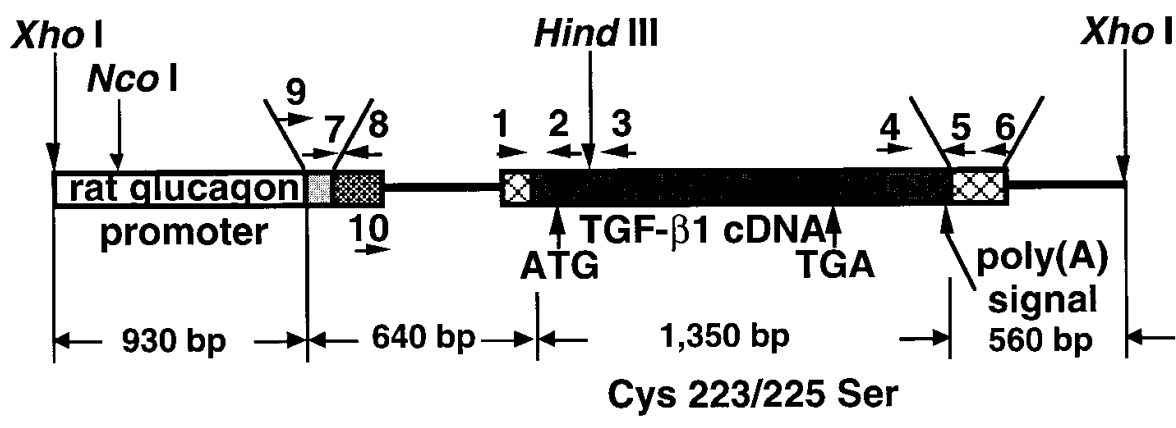

rat glucagon exon 1
rabbit $\beta$-globin exon 2
rabbit $\beta$-globin exon 3 s
Figure 1. Schematic presentation of a pTGF- $\beta 1$ transgene construct. The XhoIdigested transgene fragment contains a rat glucagon promoter $(930 \mathrm{bp})$; a part of rabbit $\beta$-globin gene exon 2 , intron 2 , and exon 3 (640 bp); pTGF- $\beta 1$ cDNA (1,350 bp); and a rabbit $\beta$-globin exon 3 and 3 '-noncoding sequence including its poly(A) addition signal sequence (560 bp). Locations of primers are shown with arrows. residues produced the active pTGF- $\beta 1$, with its activity detected without acid treatment (24). To make a transgene construct, the 1,320-bp pTGF- $\beta 1$ sequence was cut out from a plasmid of pPK9a (25) provided by Dr. Greenberg (Manitoba Institute of Cell Biology), with BglII, and subcloned into a BamHI site of pBluescript (pRB601). After deleting the EcoRI site from pRB601 with ClaI and PstI digestion, a SalI-NotI fragment of 1,350 bp was subcloned into a SalI-NotI site in the transgene vector as described previously (26). The resulting transgene construct (pRB 605) under the control of RGP (27) is shown in Fig. 1. The transgene fragment obtained with XhoI digestion was microinjected into fertilized ova of NOD mice.

Integration of the transgene was detected by PCR using genomic DNA extracted from tail. To detect chimeric sequences between the flanking $\beta$-globin sequence and the pTGF- $\beta 1$ cDNA sequence, pairs of PCR primers were designed (Fig. 1 and Table I). Primer pairs $a, b$, and $c$ amplify DNA sequences of $5^{\prime}$-pTGF- $\beta 1,3^{\prime}$-pTGF- $\beta 1$, and RGP, respectively. Primer pairs $d$ and e amplify the Tg pTGF- $\beta 1$ mRNA, and the $3^{\prime}$-portion of endogenous murine TGF- $\beta 1$ (mTGF$\beta 1$ ) mRNA, respectively. Primer sequences in these pairs had the $3^{\prime}$ - end and penultimate bases specific to pTGF- $\beta 1$ and mTGF- $\beta 1$ sequences, respectively. All primer pairs for RT-PCR were designed in separate exons to cross an intron.

PCR detection of $p T G F-\beta 1$ or $m T G F-\beta 1 m R N A$ in islets. Islets were isolated from NOD-RGP-TGF- $\beta 1$, NOD/scid, and NOD mice at $10 \mathrm{wk}$ of age using a collagenase method as described previously (28). Total RNA was isolated with ISOGEN (Nippon Gene, Tokyo, Japan). Total RNA in $1 \mu \mathrm{g}$ was reverse-transcribed as previously described (28). Target sequences were amplified using the first-strand cDNA as a template after 37 cycles at $94^{\circ} \mathrm{C}$ for $1 \mathrm{~min}, 56^{\circ} \mathrm{C}$ for $1 \mathrm{~min}$, and $72^{\circ} \mathrm{C}$ for $2 \mathrm{~min}$. After an extra extension reaction for $8 \mathrm{~min}, \mathrm{PCR}$ products were electrophoresed on an $8 \%$ polyacrylamide gel. The amplified DNAs extracted from a polyacrylamide gel by the "crush and soak" method were subcloned to TA vectors (Invitrogen, San Diego, CA), and the DNA sequences determined with the ABI 377 sequencer confirmed their identities of pTGF- $\beta 1$ or mTGF- $\beta 1$.

The $\beta$-actin mRNA (which was amplified with a primer set of $f$; Table I) was used as an internal control.

ELISA and bioassay of TGF- $\beta 1$. ELISA of the serum of NOD-

Table I. PCR Primers Used to Amplify Genomic DNA and mRNAs for Cytokines or $\beta$-actin

\begin{tabular}{|c|c|c|c|}
\hline Set & $\begin{array}{l}\text { Forward (S) primer } \\
\text { Reverse (A) primer }\end{array}$ & Primer sequence & Target (size in bp) \\
\hline \multirow{4}{*}{ a) } & oRB1669S & 5'-GCTGGTTGTTGTGCTGTCTC-3' & $5^{\prime}$-pTGF- $\beta 1(170)$ \\
\hline & oRB1671A & 5'-TGGTCTTGCAGGTGGACAGT-3' & \\
\hline & oRB1669S & (as above) & $5^{\prime}$-pTGF- $\beta 1$ (189) \\
\hline & oRB2118A & 5'-TTCACCAGCTCCATGTCGAT-3' & \\
\hline \multirow{4}{*}{ b) } & oRB1672S & 5'-AGATCCACTAGTTCTAGAGC-3' & $3^{\prime}$-pTGF- $\beta 1(160)$ \\
\hline & oRB1673A & 5'-CCAGAAGTCAGATGCTCAAG-3' & \\
\hline & oRB1672S & (as above) & $3^{\prime}$-pTGF- $\beta 1$ (187) \\
\hline & oRB409A & 5'-TAGCCAGAAGTCAGATGCTC-3' & \\
\hline \multirow[t]{4}{*}{ c) } & oRB1678S & 5'-TTGGGCGCAGAACACACTCA-3' & Rat glucagon exon 1 and rabbit $\beta$-globin exon 2 (119) \\
\hline & oRB1680A & 5'-ACTCACCCTGAAGTTCTCAG-3' & \\
\hline & oRB1679S & 5'-CAAAGTTCCCAAAGGAGCTC-3' & Promoter* (101) \\
\hline & oRB1680A & (as above) & \\
\hline \multirow{2}{*}{ d) 10} & oRB627S & 5'-AGCTTGGATCCTGAGAACTTC-3' & pTGF- $\beta 1(180)$ \\
\hline & oRB1671A & (as above) & \\
\hline \multirow[t]{2}{*}{ e) } & oRB2322S & 5'-CATGAACCGGCCCTTCCTGC-3' & mTGF- $\beta 1(348)$ \\
\hline & oRB2633A & 5'-CTAGACGATGGGCAGTGGATCCAAA-3' & \\
\hline \multirow[t]{2}{*}{ f) } & oRB1634S & 5'-GTGGGCCGCTCTAGGCACCA-3' & $\beta$-actin $(245)$ \\
\hline & oRB1635A & 5'-CGGTTGGCCTTAGGGTTCAGG3' & \\
\hline
\end{tabular}

Primer sets of a, b, and c were used to amplify genomic DNA, and those of $\mathrm{d}$, e, and $\mathrm{f}$ were used to amplify mRNAs. *Promoter represents an RGP sequence. The positions of primers are shown in Fig. 1. 
RGP-TGF- $\beta 1$ and nontransgenic mice at $16 \mathrm{wk}$ of age was performed using an ELISA kit (Morinaga, Kanagawa, Japan). The antibody only detects the active form TGF- $\beta 1$, including both pTGF- $\beta 1$ and endogenous mTGF- $\beta 1$ in their active forms. TGF- $\beta 1$ was assayed before and after converting TGF- $\beta 1$ in its latent form into its active form by acid treatment. In brief, samples and TGF- $\beta 1$ standards were added to a 96-well plate, which was coated with anti-TGF- $\beta 1$ yolk immunoglobulin $(\operatorname{IgY})$, and incubated at room temperature for $1 \mathrm{~h}$. After washing, the plate was incubated with biotinylated anti-TGF- $\beta 1 \mathrm{IgY}$. Peroxidase-conjugated streptavidin and orthophenylene diamine as a substrate were sequentially added, and the color reaction developed at room temperature was assessed at the wavelength of $492 \mathrm{~nm}$ after stopping the reaction with $1 \mathrm{~N} \mathrm{HCl}$.

Bioassay of TGF- $\beta 1$ depends on the growth inhibition of mink lung epithelial cells (Mv1Lu; CCL-64: ATCC) (29) and it detects bioactivity of TGF- $\beta 1$ including both pTGF- $\beta 1$ and endogenous mTGF$\beta 1$ in its active form. The bioassay of TGF- $\beta 1$ detected the bioactivity of TGF- $\beta 1$ in the culture supernatant of 80 islets per one mouse, using NOD-RGP-TGF- $\beta 1$ and nontransgenic mice $(n=6$ for each) at $16 \mathrm{wk}$ of age, at $48 \mathrm{~h}$ of culture after subtracting that of the culture medium alone.

Incidence of diabetes in NOD-RGP-TGF- $\beta 1$ or in NOD mice after adoptive transfer of splenocytes of NOD-RGP-TGF- $\beta 1$ mice. Incidence of diabetes in NOD-RGP-TGF- $\beta 1$ and nontransgenic mice was first followed until $45 \mathrm{wk}$ of age in the natural course. To examine the resistance of NOD-RGP-TGF- $\beta 1$ mice against cyclophosphamide (CY)-induced diabetes, the incidence of diabetes was then followed after the administration of $200 \mathrm{mg} / \mathrm{kg} \mathrm{CY}$ (Shionogi, Osaka, Japan) twice to six NOD-RGP-TGF- $\beta 1$ mice including three males and three females, and six sex-matched littermates at 10 and $12 \mathrm{wk}$ of age.

To examine the ability of splenocytes of NOD-RGP-TGF- $\beta 1$ mice to induce diabetes, 2.0-3.0 $\times 10^{7}$ splenocytes of female NODRGP-TGF- $\beta 1$ mice or nondiabetic female littermates at $20 \mathrm{wk}$ of age were intraperitoneally transferred to NOD mice at $8 \mathrm{~d}$ of age. After $37 \mathrm{~d}$ of age, the adoptive transfer was performed without sublethal irradiation as previously described (28). Mice were considered diabetic when nonfasting blood glucose (BG) concentrations were $>14 \mathrm{mM}$.

Adoptive transfer of diabetogenic splenocytes, $\mathrm{CD} 4^{+}$, and $\mathrm{CD} 8^{+}$ clone cells to NOD-RGP-TGF- $\beta 1$ mice. Diabetogenic splenocytes were prepared from the spleen of diabetic female NOD mice. To lyse the red cells, splenocytes were exposed to $0.84 \%$ ammonium chloride at $37^{\circ} \mathrm{C}$ for 5 min twice. Remaining cells were washed with PBS and resuspended in $150 \mu \mathrm{l}$ of PBS. Islet $\beta$ cell-specific CD4 ${ }^{+}$Th1 clones (4-1-L.6 and 4-1-G.4; abbreviated as L and G) were maintained as previously described $(28,30)$. Islet $\beta$ cell-specific $\mathrm{CD}^{+} \mathrm{T}$ cell clones (G9-C8, TGNF-C8), which were isolated from the lymphocytic infiltrate in the islets of NOD mice at $7 \mathrm{wk}$ of age (31), were maintained in Clicks medium (Sigma Chemical Co., St. Louis, MO) supplemented with $5 \%$ FBS (Hyclone, Logan, UT) and $10 \mathrm{U} / \mathrm{ml}$ of recombinant mIL-2 (Becton Dickinson, Bedford, MA) with $2 \mathrm{ml}$ of culture medium. Proliferation of two $\mathrm{CD}^{+} \mathrm{T}$ cell clones was stimulated by culturing $10^{6}$ cells of each clone with irradiated dispersed NOD islet cells as antigen (28) at two weekly intervals.

Three types of lymphocytes, i.e., $0.5-2.0 \times 10^{7}$ diabetogenic splenocytes, $2.0-3.0 \times 10^{6}$ diabetogenic $\mathrm{CD}^{+}{ }^{+} \mathrm{Th} 1$ clone cells of $\mathrm{L}$ or $\mathrm{G}$, or 2.0-3.0 $\times 10^{6}$ diabetogenic $\mathrm{CD}^{+}$clone cells of G9-C8 or TGNF$\mathrm{C} 8$, each in $150 \mu \mathrm{l}$ of PBS, were intraperitoneally transferred to NOD-RGP-TGF- $\beta 1$ or nontransgenic mice at $8 \mathrm{~d}$ of age. The same protocol of $\mathrm{CY}$ administration and $\mathrm{BG}$ determination was performed as above, and the incidence of diabetes was compared after the adoptive transfer of three types of lymphocytes.

Histological analysis and grading of insulitis. Six NOD-RGP-TGF$\beta 1$ mice including three females and three males and six age- and sexmatched littermates were killed at 10 and 25 wk of age. Pancreas was excised as described previously (28). More than 100 islets in total per mouse were analyzed by the uninformed pathologist. The histological grades of insulitis were evaluated for individual islets using the fol- lowing criteria on the grade of insulitis from 0 to 3 : 0 , intact islet without any infiltration; 1 , infiltration surrounding or involving $<25 \%$ of the islet area; 2, infiltration involving between 25 and $50 \%$ of the islet area; and 3 , infiltration involving $>50 \%$ of the islet area. Insulin and glucagon were stained, respectively, with guinea pig anti-porcine insulin antibody and rat anti-human glucagon antibody (Dako, Glostrup, Denmark).

Statistical analysis of insulitis grades and incidence of diabetes. Student's unpaired $t$ test was used for the statistical analysis of insulitis grades as previously described (28). For comparing two ratios $\left(Q_{1}\right.$, $Q_{2}$ ) of diabetes after the adoptive transfer, a normal distribution curve, of which mean and variance are $Q_{1}-Q_{2}$ and $Q_{1}\left(1-Q_{1}\right) / n_{1}+$ $Q_{2}\left(1-Q_{2}\right) / n_{2}$, respectively, was used ( $n=$ sample number). $P<0.05$ was considered significant.

\section{Results}

Generation of NOD-RGP-TGF- $\beta 1$ mice. Of 48 progeny screened with PCRs and Southern blot analysis, two female founder NOD-RGP-TGF- $\beta 1$ mice were obtained. These two founders were subsequently bred to NOD mice and two independent lines were established. The copy numbers of transgene in two lines of NOD-RGP-TGF- $\beta 1$ mice were assessed with semi-quantitative Southern blot analysis as 6 and 10 per haploid genome, respectively (data not shown).

$R T-P C R$ detection of TGF- $\beta 1 \mathrm{mRNA}$, ELISA and bioassay of TGF- $\beta 1$. The Tg expression of pTGF- $\beta 1$ was confirmed with RT-PCR of the total RNA obtained from islets of NOD-RGP-TGF- $\beta 1$ mice. The amplified 180-bp DNA fragment (with a primer set of d) (Table I) was confirmed by se-
A

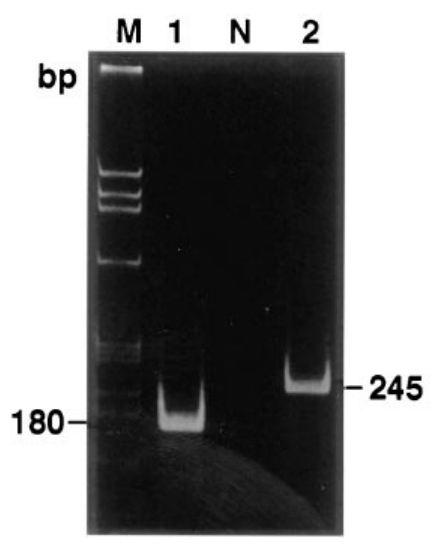

B

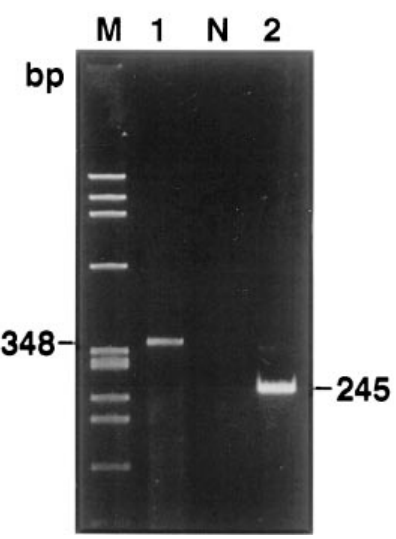

Figure 2. RT-PCR detection of Tg pTGF- $\beta 1$ mRNA or mTGF- $\beta 1$ mRNA. Ethidium bromide-stained polyacrylamide gels show RT-PCR-amplified fragments of pTGF- $\beta 1$, mTGF- $\beta 1$, and $\beta$-actin mRNA. Total RNA in $1 \mu \mathrm{g}$ isolated from islets of NOD-RGP-TGF$\beta 1(A)$ or NOD/scid mice $(B)$ was reverse-transcribed using random hexamer primers. $(A)$ RT-PCR amplification of pTGF- $\beta 1$ mRNA from NOD-RGP-TGF- $\beta 1$ mice is shown. Lane 1 shows a 180 -bp RTPCR-amplified pTGF- $\beta 1$ mRNA as indicated with an arrow. Lane 2 shows a 245-bp RT-PCR-amplified fragment of $\beta$-actin mRNA as a control. (B) RT-PCR amplification of mTGF- $\beta 1$ mRNA from NOD/ scid mice is shown. Lane 1 shows a 348-bp RT-PCR-amplified endogenous mTGF- $\beta 1$ mRNA as indicated with an arrow. Lane 2 shows a 245-bp RT-PCR-amplified fragment of $\beta$-actin mRNA as a control. Lane $N$ is the same as lane 1 in $A$ or $B$ except that RTase was omitted from the reaction mixture. 


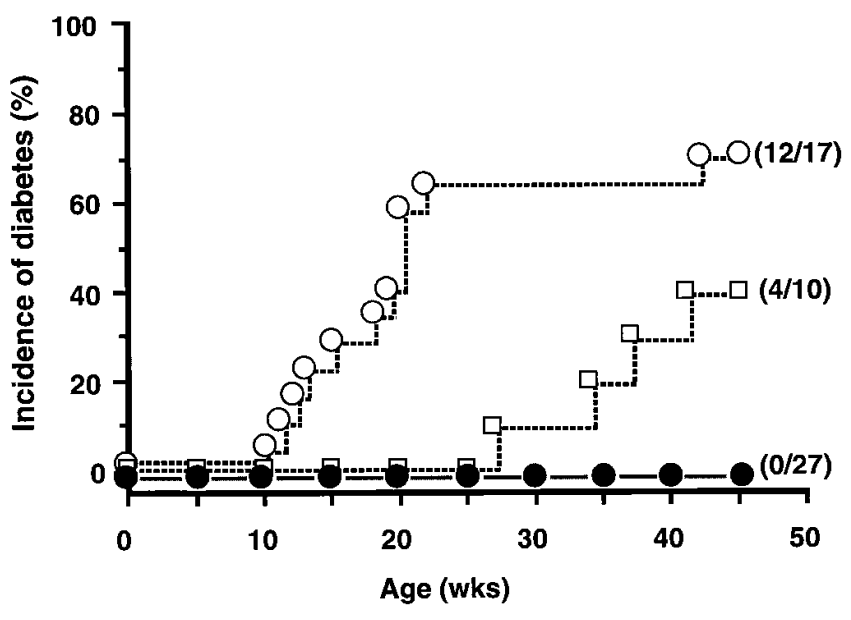

Figure 3. Time course of the incidence of diabetes in NOD-RGPTGF- $\beta 1$ mice. Time courses of the incidence of diabetes are shown for 27 NOD-RGP-TGF- $\beta 1$ mice including 12 males and 15 females, and 27 nontransgenic mice including 10 males and 17 females. Closed circles denote NOD-RGP-TGF- $\beta 1$ mice, open squares and circles denote male and female nontransgenic mice, respectively.

quencing to be derived from pTGF- $\beta 1$ mRNA after splicing out the $\beta$-globin intron (Fig. $2 A$ ). The endogenous mTGF- $\beta 1$ mRNA was detected as the 348-bp PCR-amplified fragment in NOD/scid mice (Fig. $2 B$ ) or NOD mice (data not shown) at 10 wk of age (with a primer set of e), of which identity was confirmed by sequencing.

TGF- $\beta 1$ levels with bioassay of the culture supernatant of 80 islets per one mouse isolated from NOD-RGP-TGF- $\beta 1$ and nontransgenic mice ( $n=6$ for each) were $211 \pm 70$ and $39 \pm 49$ $\mathrm{pg} / \mathrm{ml}$, respectively. The serum levels of TGF- $\beta 1$ with ELISA of NOD-RGP-TGF- $\beta 1$ and nontransgenic mice were $17 \pm 2.7$ and $15 \pm 2.4 \mathrm{ng} / \mathrm{ml}$ ( $n=8$ for each) at $16 \mathrm{wk}$ of age, respectively, and they were $31 \pm 5.6$ and $23 \pm 6.2 \mathrm{ng} / \mathrm{ml}(n=6$ for each) at $60 \mathrm{wk}$ of age, respectively, both without significant difference.

Incidence of diabetes in the natural course and after $C Y$ administration. None of 27 NOD-RGP-TGF- $\beta 1$ mice in two lines including 8 males plus 10 females from one line and 4 males and 5 females from another line developed diabetes by 45 wk of age (Fig. 3). None of 13 NOD-RGP-TGF- $\beta 1$ mice including 4 males and 9 females became diabetic, even at $60 \mathrm{wk}$ of age. They were consistently normoglycemic and a mean BG concentration was $7.7 \mathrm{mM}$ at $45 \mathrm{wk}$ of age. In contrast, female and male littermates spontaneously started to develop diabetes at 10 and 27 wk of age, respectively, and the cumulative incidence of diabetes (the number of diabetic mice/the total number of examined mice) was $71 \%(12 / 17)$ in females, and $40 \%(4 / 10)$ in males, respectively, at $45 \mathrm{wk}$ of age. This incidence is comparable to the incidence of diabetes in our NOD mice colony of $63 \%(5 / 8)$ in female and $25 \%(2 / 8)$ in male NOD mice at $30 \mathrm{wk}$ of age.

After the administration of CY twice at 10 and 12 wk of age, five (three females and two males) out of six nontransgenic mice (three females and three males) developed overt diabetes at 17 wk of age and later, but none of six sex-matched NOD-RGP-TGF- $\beta 1$ mice developed diabetes even at $20 \mathrm{wk}$ of age (Fig. 4).
Histological analysis of islets and grading of insulitis. Most islets of nontransgenic mice exhibited insulitis of grade 1 or 2 (Fig. $5 A$ ), which appeared higher than that in NODRGP-TGF- $\beta 1$ mice (Fig. $5 D$ ). In contrast, most islets of NODRGP-TGF- $\beta 1$ mice exhibited no or mild lymphocytic infiltration of grade 1 (Fig. $5 \mathrm{D}$ ), and no acinar change was observed. No remarkable histology except for insulitis was observed in NOD-RGP-TGF- $\beta 1$ mice. To quantitatively assess the histological grade of insulitis, islets of NOD-RGP-TGF- $\beta 1$ mice including three males and three females, and age- and sexmatched littermates were graded for the severity of insulitis according to our criteria. At $10 \mathrm{wk}$ of age, NOD-RGP-TGF- $\beta 1$ mice had the insulitis score of 0.72 compared with 1.42 in nontransgenic mice $(P<0.0001)$ (Table II). The suppression of mean insulitis grade in NOD-RGP-TGF- $\beta 1$ mice was associated with the parallel downward shift in the percentage distribution of islets among four insulitis grades (Table II). At $25 \mathrm{wk}$ of age, NOD-RGP-TGF- $\beta 1$ mice had the insulitis score of 0.93 compared with 1.74 in nontransgenic mice $(P<0.0001)$ (Table II). The number and size of islets did not significantly decrease from those in nontransgenic mice, as judged by antiinsulin immunostaining (Fig. 5, $B$ and $E$ ). These islets contained glucagon-positive cells at an apparently normal ratio (Fig. 5, $C$ and $F$ ).

Incidence of diabetes in NOD mice after adoptive transfer of splenocytes of NOD-RGP-TGF- $\beta 1$ mice. The adoptive transfer of splenocytes of female NOD-RGP-TGF- $\beta 1$ mice from 17 to $19 \mathrm{wk}$ of age to NOD mice at $8 \mathrm{~d}$ of age after CY administration did not transfer diabetes $(0 / 7)$, while the adoptive transfer of splenocytes from age-matched female nondiabetic NOD mice after $C Y$ administration transferred diabetes to NOD mice $(2 / 6)(P<0.05)$. This confirmed the decreased

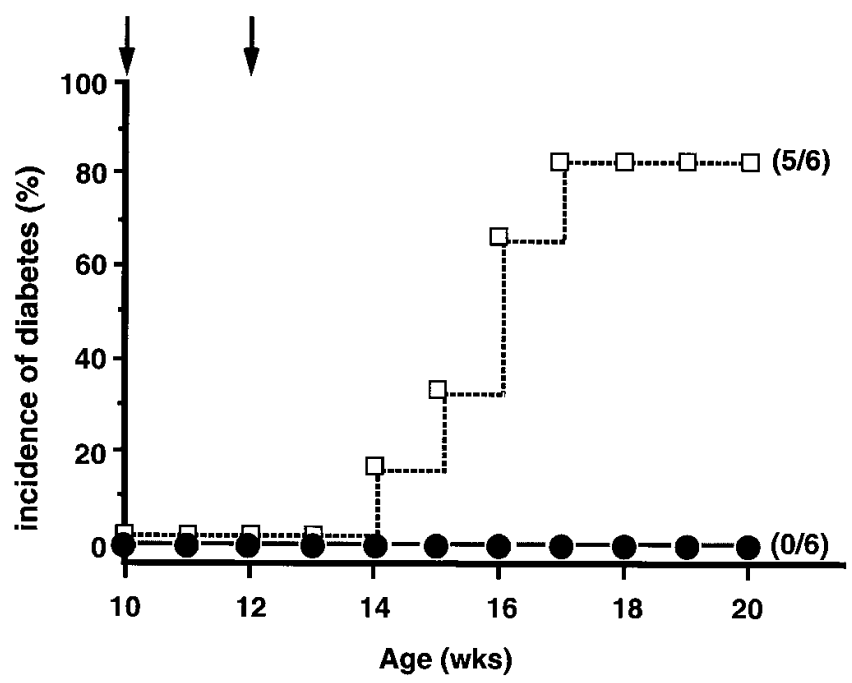

Figure 4. Time course of the incidence of diabetes in NOD-RGPTGF- $\beta 1$ mice after $\mathrm{CY}$ administration. Time courses of the incidence of diabetes are shown for six NOD-RGP-TGF- $\beta 1$ mice including three males and three females, and six nontransgenic mice including three males and three females after the administration of CY at 200 $\mathrm{mg} / \mathrm{kg}$ at 10 and $12 \mathrm{wk}$ of age, as indicated by arrows. Closed circles denote NOD-RGP-TGF- $\beta 1$ mice, open squares denote nontransgenic mice, and numbers in parentheses denote the final incidence of diabetes at $17 \mathrm{wk}$ of age. 

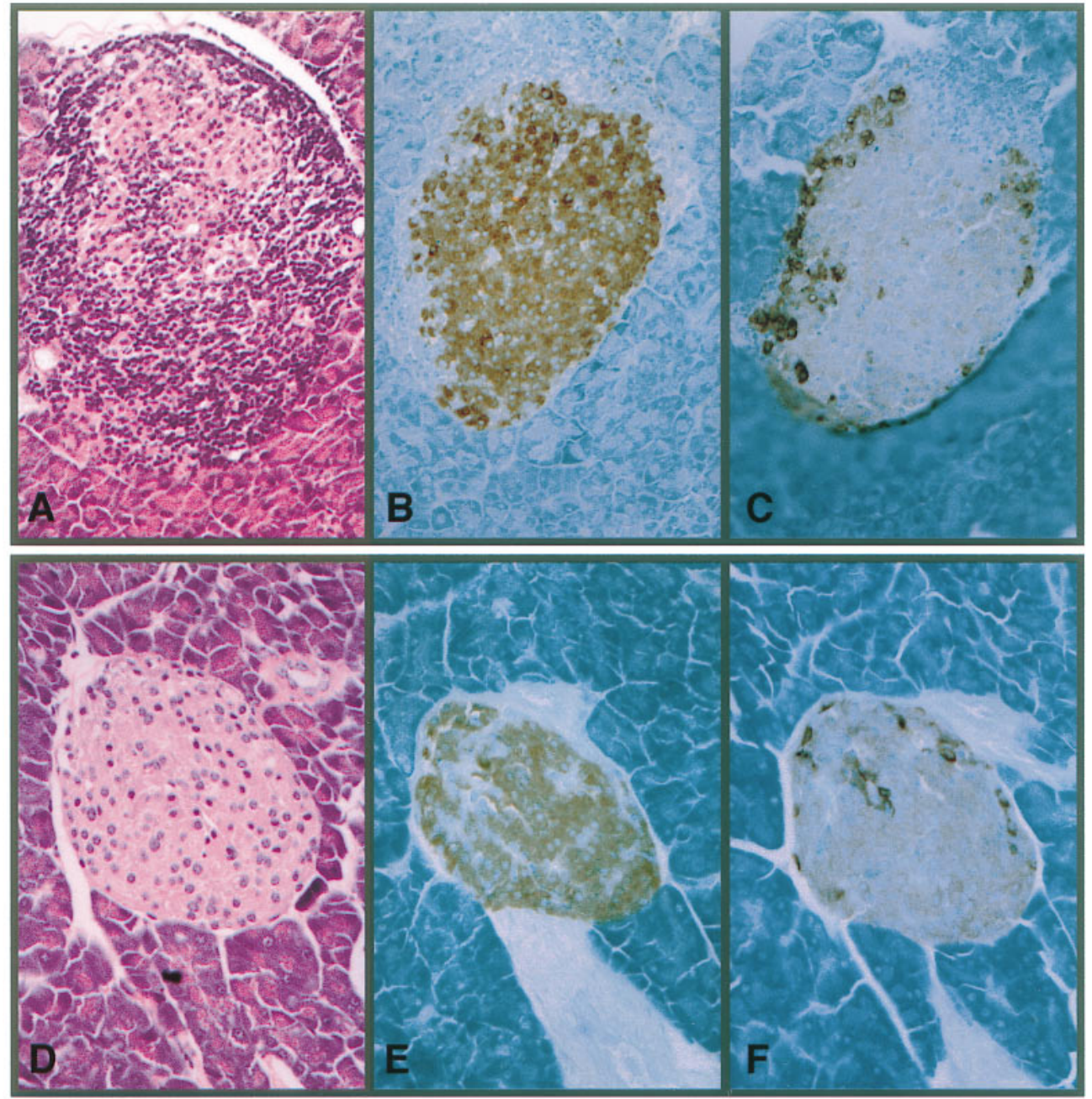

Figure 5. Histology of pancreas. Section of the pancreas from NOD-RGP-TGF- $\beta 1$ mice at 10 wk of age. $A-C$ show the histology of nontransgenic mice, while $D-F$ show that of NODRGP-TGF- $\beta 1$ mice. Hematoxylin and eosin staining shows the absence of insulitis in $D$ and insulitis of grade 1.42 in $A . B$ and $E$ show insulin staining whereas $C$ and $F$ show glucagon staining. ability of splenocytes of NOD-RGP-TGF- $\beta 1$ mice to induce diabetes in neonatal NOD mice.

Incidence of diabetes in NOD-RGP-TGF- $\beta 1$ mice after adoptive transfer of diabetogenic lymphocytes. As shown in Fig. 6 and Table III, the incidence of diabetes in nontransgenic mice at $47 \mathrm{~d}$ of age for three types of diabetogenic lymphocytes was $77 \%(10 / 13)$ for diabetogenic female NOD splenocytes after CY administration, 75\% (6/8) for $\mathrm{CD}^{+}$Th1 clone cells after $\mathrm{CY}$ administration, and $50 \%(3 / 6)$ for $\mathrm{CD}^{+}$clone cells after $\mathrm{CY}$ administration. The incidence of diabetes after the adoptive transfer to nontransgenic mice in regard to two dif- ferent Th1 clones of $\mathrm{L}$ and $\mathrm{G}$, or two different $\mathrm{CD}^{+}$clones of G9-C8 and TGNF-C 8 was $2 / 3$ and $4 / 5$, or $1 / 3$ and $2 / 3$, respectively.

However, the incidence of diabetes after the adoptive transfer of three types of diabetogenic lymphocytes to NODRGP-TGF- $\beta 1$ mice was as low as $29 \%(2 / 7)$ for diabetogenic splenocytes after CY administration, $25 \%(2 / 8)$ for $\mathrm{CD}^{+}$Th1 clone cells after CY administration, and $0 \%(0 / 6)$ for $\mathrm{CD}^{+}$ clone cells after CY administration. The incidence of induced diabetes for each cell type was significantly lower than that in nontransgenic mice $(P<0.05)$. No incidence of diabetes was

Table II. Percent Distribution of Islets among Four Insulitis Grades

\begin{tabular}{|c|c|c|c|c|c|c|c|c|c|}
\hline \multirow[b]{2}{*}{ Group } & \multirow[b]{2}{*}{ Treatment conditions (age) } & \multirow{2}{*}{$\begin{array}{l}\text { Number } \\
\text { of mice }\end{array}$} & \multicolumn{4}{|c|}{ Percent distribution among insulitis grades } & \multirow{2}{*}{$\begin{array}{c}\text { Mean } \\
\text { grade } \pm S D\end{array}$} & \multirow{2}{*}{$\begin{array}{l}\text { Number } \\
\text { of islets }\end{array}$} & \multirow[b]{2}{*}{$P$ value (group) } \\
\hline & & & 0 & 1 & 2 & 3 & & & \\
\hline 1 & Nontransgenic (10 wk) & 6 & 13.6 & 46.1 & 26.2 & 14.1 & $1.42 \pm 0.23$ & 119 & \\
\hline 2 & NOD-RGP-TGF- $\beta 1$ (10 wk) & 6 & 37.6 & 53.5 & 8.9 & 0 & $0.72 \pm 0.12$ & 123 & $P<0.0001(1)$ \\
\hline 3 & Nontransgenic (25 wk) & 6 & 0 & 47.8 & 29.8 & 22.4 & $1.74 \pm 0.13$ & 178 & \\
\hline 4 & NOD-RGP-TGF- $\beta 1$ (25 wk) & 6 & 24.8 & 60.3 & 13.7 & 1.2 & $0.93 \pm 0.01$ & 157 & $P<0.0001$ \\
\hline
\end{tabular}

Group numbers 1 and 3 denote age- and sex-matched nontransgenic mice. $P$ value denotes the significance level in Student's unpaired $t$ test with data of the group number indicated in parentheses. 

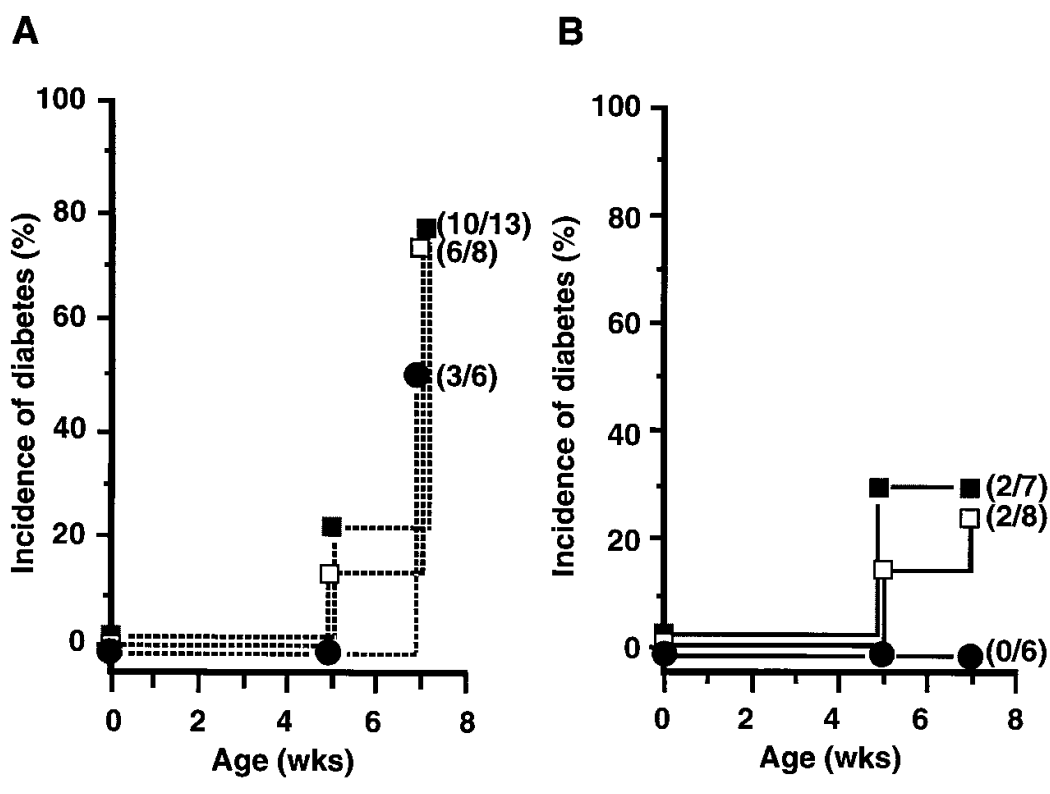

Figure 6. Time course of the incidence of diabetes after adoptive transfer of three types of diabetogenic lymphocytes. $(A)$ The changes in the incidence of diabetes after the adoptive transfer of $0.5-2.0 \times 10^{7}$ diabetogenic splenocytes after $\mathrm{CY}$ administration (filled boxes), 2.0-3.0 $\times 10^{6}$ diabetogenic $\mathrm{CD} 4^{+}$Th1 clone cells after $\mathrm{CY}$ administration (open boxes) and 2.0$3.0 \times 10^{6}$ diabetogenic $\mathrm{CD}^{+}$clone cells after $\mathrm{CY}$ administration (filled circles) to nontransgenic mice are presented. Adoptive transfer was at $8 \mathrm{~d}$ of age, nonfasting BG measurement at 35 and $47 \mathrm{~d}$ of age, and $\mathrm{CY}$ administration at $37 \mathrm{~d}$ of age. The incidence of diabetes started from 0 in all groups at $8 \mathrm{~d}$ of age and reached the levels (number of diabetic mice/total number of examined mice at $47 \mathrm{~d}$ of age) as shown in parentheses. $(B)$ The changes in the incidence of diabetes after the adoptive transfer of $0.5-2.0 \times 10^{7}$ diabetogenic splenocytes after $\mathrm{CY}$ administration (filled boxes), 2.0-3.0 $\times 10^{6}$ diabetogenic $\mathrm{CD} 4^{+}$Th1 clone cells after $\mathrm{CY}$ administration (open boxes), and 2.0 $3.0 \times 10^{6}$ diabetogenic $\mathrm{CD}^{+}$clone cells after $\mathrm{CY}$ administration (filled circles) to NOD-RGP-TGF- $\beta 1$ mice are presented. observed in NOD-RGP-TGF- $\beta 1(0 / 6)$ or nontransgenic mice (0/6) with the administration of PBS plus CY administration. The incidence of diabetes after the adoptive transfer to NODRGP-TGF- $\beta 1$ mice in regard to two different Th1 clones of $\mathrm{L}$ and $G$ was $1 / 3$ and $1 / 5$, respectively. These results confirmed the resistance of NOD-RGP-TGF- $\beta 1$ mice against three types of diabetogenic effector lymphocytes.

\section{Discussion}

To understand the effect of local paracrine TGF- $\beta 1$ on autoimmune diabetes, we produced NOD-RGP-TGF- $\beta 1$ mice in which pTGF- $\beta 1$ is expressed in islet $\alpha$ cells of NOD mice under the control of the rat glucagon promoter. The higher bioactivity of TGF- $\beta 1$ in the islet culture supernatant in NODRGP-TGF- $\beta 1$ than that of nontransgenic mice confirmed the local production of bioactive pTGF- $\beta 1$ in NOD-RGP-TGF- $\beta 1$

Table III. Incidence of Diabetes in Young NOD-RGP-TGF- $\beta 1$ or Nontransgenic Mice after the Adoptive Transfer of Three Types of Diabetogenic Lymphocytes

\begin{tabular}{lccccc}
\hline $\begin{array}{c}\text { Adoptively transferred } \\
\text { lymphocytes }\end{array}$ & $\begin{array}{c}\text { LM } \\
\text { or Tg }\end{array}$ & $\begin{array}{c}\text { Number } \\
\text { of mice }\end{array}$ & $\begin{array}{c}\text { Incidence of } \\
\text { transferred } \\
\text { diabetes (\%) }\end{array}$ & $\begin{array}{c}\text { Statistical } \\
\text { significance }\end{array}$ \\
\hline Diabetic splenocytes & LM & 13 & $10 / 13$ & $(77 \%)$ & \\
Diabetic splenocytes & Tg & 7 & $2 / 7$ & $(29 \%)$ & $P<0.05$ \\
G or L CD4 $^{+}$clone & LM & 8 & $6 / 8$ & $(75 \%)$ & \\
$\mathrm{G} \mathrm{or} \mathrm{L} \mathrm{CD4}^{+}$clone & Tg & 8 & $2 / 8$ & $(25 \%)$ & $P<0.05$ \\
CD $^{+}$clones & LM & 6 & $3 / 6$ & $(50 \%)$ & \\
$\mathrm{CD}^{+}$clones & Tg & 6 & $0 / 6$ & $(0 \%)$ & $P<0.05$ \\
PBS & LM & 6 & $0 / 6$ & $(0 \%)$ & \\
PBS & Tg & 6 & $0 / 6$ & $(0 \%)$ & \\
& & & & & \\
\hline
\end{tabular}

LM and Tg stand for nontransgenic mice and NOD-RGP-TGF- $\beta 1$ mice. Statistical significance was examined between $\mathrm{LM}$ and $\mathrm{Tg}$. mice. The active form was reported to be 14 times stronger in bioactivity than the latent pTGF- $\beta 1$ (24). The ELISA level of TGF- $\beta 1$ in the serum before acid treatment was not detectable. Total TGF- $\beta 1$ levels in the serum after acid treatment were not different between Tg and nontransgenic mice. Although the increase of bioactive pTGF- $\beta 1$ in the serum could not be ruled out, pTGF- $\beta 1$ in NOD-RGP-TGF- $\beta 1$ mice was expected to exhibit its major functions in the islet compartment.

In contrast to the complete abrogation of diabetes in two independent lines of NOD-RGP-TGF- $\beta 1$ mice without causing the anatomical distortion in our study, the Tg expression of pTGF- $\beta 1$ by the albumin promoter caused the systemic high concentrations of pTGF- $\beta 1$ and glomerulosclerosis with the mesangial proliferation (32). The Tg expression of pTGF- $\beta 1$ by the insulin promoter had chronic exocrine pancreatitis, accumulation of extracellular matrix, and disorganization of islets due to the local excessive production of pTGF- $\beta 1$ in the islets $(20,21)$. The intact islets (Fig. 5) and the absence of glomerulosclerosis in our NOD-RGP-TGF- $\beta 1$ mice (data not shown) support that the magnitude and duration of local TGF$\beta 1$ levels must be optimum to prevent autoimmune diabetes without causing morphological changes of islets. This was supported by the small size of islets in homozygous NOD-RGPTGF- $\beta 1$ mice, which secrete pTGF- $\beta 1$ in larger amounts than hemizygous NOD-RGP-TGF- $\beta 1$ mice, presumably due to the effects of pTGF- $\beta 1$ on islet differentiation (data not shown). The complete abrogation of autoimmune diabetes by $\mathrm{Tg}$ pTGF- $\beta 1$ in NOD-RGP-TGF- $\beta 1$ mice and islet $\beta$ cell transgenics for IL-4 in the NOD genetic background (19) are compatible with the notion that the autoimmune destruction of islet $\beta$ cells is regulated by the balance between tolerance and its disruption in the periphery of the islet compartment.

As the protection mechanisms against autoimmune diabetes in NOD mice by local paracrine TGF- $\beta 1$, direct protection against effector lymphocytes is most likely. The protective capacity of TGF- $\beta 1$ against islet $\beta$ cell-specific $\mathrm{CD} 4^{+}$and $\mathrm{CD} 8^{+}$ 
effector lymphocytes is expected to disrupt the vicious cycle of antigen presentation after islet $\beta$ cell destruction and function as the most likely protection mechanism. The decreased generation of autoreactive $\mathrm{T}$ cells and the generation of regulatory $\mathrm{T}$ cells may afford possible mechanisms of protection.

The majority of islet-infiltrating lymphocytes expressing TGF- $\beta 1$, IL-4, and IL-10 was reported to contribute to the tolerance induced by oral insulin against LCMV-induced insulitis and diabetes (18). IL-10 in vitro induces differentiation of antigen-specific $\mathrm{CD}^{+}$regulatory $\mathrm{T}$ cell subset of $\operatorname{Tr} 1$ which secretes IL-10 and TGF- $\beta 1$, and Tr1 suppresses experimental autoimmune colitis induced by pathogenic $\mathrm{CD}^{+} \mathrm{CD}^{45} \mathrm{RB}^{\text {high }}$ splenic $\mathrm{T}$ cells (33). The adoptive transfer of islet-infiltrating autoreactive $\mathrm{CD}^{+}$cell clone of I.S. 2.15 (34) or $\mathrm{CD}^{+}$suppressor T cell clone of NY4.2 (35), both secreting TGF- $\beta 1$, prevents autoimmune diabetes in NOD mice. These observations suggest the importance of local TGF- $\beta 1$ itself and regulatory $\mathrm{T}$ cell subsets secreting TGF- $\beta 1$ in preventing autoimmune colitis and diabetes. The possible induction of antigen-specific regulatory $\mathrm{T}$ cell subsets in NOD-RGP-TGF- $\beta 1$ mice is being tested by the cotransfer experiment in our laboratory.

Decreased mean insulitis grades in NOD-RGP-TGF- $\beta 1$ mice (Table II) suggest the suppressed generation of islet $\beta$ cell-specific autoimmune lymphocytes in NOD-RGP-TGF- $\beta 1$ mice, which is consistent with the resistance of NOD-RGPTGF- $\beta 1$ mice against CY-induced diabetes and inability of splenocytes of NOD-RGP-TGF- $\beta 1$ mice to transfer diabetes to neonatal NOD mice. Activation of autoreactive T cells may be directly suppressed by the local high concentrations of TGF- $\beta 1$ in parallel with the suppressed activation of effector T cells and the protection against effector T cells.

In addition to TGF- $\beta 1$, Th2 cytokines such as IL-4 (19) and IL-10 (27) have been known to suppress autoimmune diabetes. IL-4 induces differentiation of Th0 cells to Th2 cells, while IFN- $\gamma$ and IL-12 induce differentiation of Th0 cells to Th1 cells (36-38). TGF- $\beta 1$ may prevent autoimmune diabetes in NOD mice through shifting the Th1/Th2 balance toward Th2, although Th2 induction by TGF- $\beta 1$ has not been reported. The inability of TGF- $\beta 1$ to suppress LCMV-induced autoimmune insulitis and diabetes in islet $\beta$ cell double transgenics for LCMV GP protein and TGF- $\beta 1$ (22) might be due to the excessive autocrine TGF- $\beta 1$.

Islet $\beta$ cell transgenics for TGF- $\beta 1$ were reported not to suppress allograft rejection (22). However, the protective role of $\mathrm{Tg}$ paracrine TGF- $\beta 1$ in our NOD-RGP-TGF- $\beta 1$ mice and the supposed essential role of TGF- $\beta 1$ in suppressing EAE (11), autoimmune diabetes $(34,35)$, and autoimmune colitis (33) strongly suggest that the islet isografts or allografts can be tolerized by the appropriate amount of local paracrine TGF- $\beta 1$. Because adoptive transfer of IL-10- or IL-4-transduced Th1 lymphocytes prevents autoimmune diabetes (28) or EAE (39), respectively, the molecular transduction of antigen-specific $\mathrm{T}$ cells or grafts before transplantation with the TGF- $\beta 1$ gene is expected to afford us an animal model of gene therapy for autoimmune diseases and graft survival, respectively. The implication for the long-term survival of islet isografts from NOD-RGP-TGF- $\beta 1$ to NOD mice is being tested by the transplantation experiment in our laboratory.

The NOD-RGP-TGF- $\beta 1$ mouse is one of only two available Tg models which completely prevent autoimmune diabetes in NOD mice by the Tg cytokine expression in the islet compartment, with another being islet $\beta$ cell transgenics for
IL-4 (19). The NOD-RGP-TGF- $\beta 1$ mouse thus affords us an important animal model to study the protective role of local paracrine TGF- $\beta 1$ against autoimmune diabetes. Based on our results, we concluded that autoimmune diabetes in NOD mice is not a systemic disease, and that it can be completely prevented by the Tg paracrine TGF- $\beta 1$ in the islet compartment. The protection by local paracrine TGF- $\beta 1$ against autoimmune diabetes is mediated by the protection against $\mathrm{CD} 4^{+}$and $\mathrm{CD}^{+}$effector lymphocytes.

\section{Acknowledgments}

We sincerely thank Dr. A.H. Greenberg at Manitoba Institute of Cell Biology for providing us a plasmid of pPK9. We also thank M. Akiyama for excellent technical assistance.

This study was supported in part by a grant from Otsuka Pharmaceutical Factory Inc. for Otsuka Department of Clinical and Molecular Nutrition, School of Medicine, The University of Tokushima.

\section{References}

1. Tisch, R., and H. McDevitt. 1996. Insulin-dependent diabetes mellitus. Cell. 85:291-297.

2. Kikutani, H., and S. Makino. 1992. The murine autoimmune diabetes model: NOD and related strains. Adv. Immunol. 51:285-321.

3. Kehrl, J.H., L.M. Wakefield, A.B. Roberts, S. Jakewlew, M. AlvarezMon, R.B.S.M. Derynck, and A.S. Fauci. 1986. Production of transforming growth factor $\beta$ by human $\mathrm{T}$ lymphocytes and its potential role in the regulation of T cell growth. J. Exp. Med. 163:1037-1050.

4. Kehrl, J.H., A.B. Roberts, L.M. Wakefield, S. Jakewlew, M.B. Sporn, and A.S. Fauci. 1986. Transforming growth factor $\beta$ is an important immunomodulatory protein for human B lymphocytes. J. Immunol. 137:3855-3860.

5. Rook, A.H., J.H. Kehrl, L.M. Wakefield, A.B. Roberts, M.B. Sporn, D.B. Burlington, H.C. Lane, and A.S. Fauci. 1986. Effects of transforming growth factor- $\beta$ on the functions of natural killer cells: depressed cytolytic activity and blunting of interferon responsiveness. J. Immunol. 136:3916-3920.

6. Espevik, T., I.S. Figari, M.R. Shalaby, G.A. Lackides, G.D. Lewis, H.M. Shepard, and M.A. Palladino, Jr. 1987. Inhibition of cytokine production by cyclosporin A and transforming growth factor $\beta$. J. Exp. Med. 166:571-576.

7. Chantry, D., M. Turner, E. Abney, and M. Feldman. 1989. Modulation of cytokine production by transforming growth factor- $\beta 1$. J. Immunol. 142:42954300 .

8. Shull, M.M., I. Ormsby, A.B. Kier, S. Pawlowski, R.J. Diebold, M. Yin, R. Allen, C. Sidman, G. Proetzel, D. Calvin, N. Annunziata, and T. Doetschman. 1992. Targeted disruption of the mouse transforming growth factor- $\beta 1$ gene results in multifocal inflammatory disease. Nature. 359:693-699.

9. Kulkarni, A.B., C.G. Huh, D. Becker, A. Geiser, M. Lyght, K.C. Flanders, A.B. Roberts, M.B. Sporn, J.M. Ward, and S. Karlsson. 1993. Transforming growth factor $\beta 1$ null mutation in mice causes excessive inflammatory response and early death. Proc. Natl. Acad. Sci. USA. 90:770-774.

10. Kiefer, R., K. Funa, T. Schweitzer, S. Jung, O. Bourde, K.V. Toyka, and H.P. Hartung. 1996. Transforming growth factor-beta 1 in experimental autoimmune neuritis. Cellular localization and time course. Am. J. Pathol. 148: 211-223.

11. Kulluvilla, A.P., R. Shah, G.M. Hochwald, H.D. Liggitt, M.A. Palladino, and G.J. Thorbecke. 1991. Protective effect of transforming growth factor $\beta 1$ on experimental autoimmune diseases in mice. Proc. Natl. Acad. Sci. USA. 88: 2918-2921.

12. Racke, M.K., S. Dhib-Jalbut, B. Canella, P.S. Albert, C.S. Raine, and D.E. Macfarlin. 1992. Prevention and treatment of chronic relapsing experimental allergic encephalomyelitis by transforming growth factor- $\beta 1$. J. Immunol. 146:3012-3017.

13. Miller, A., O. Lider, A.B. Roberts, M.B. Sporn, and H.L. Weiner. 1992. Suppressor $\mathrm{T}$ cells generated by oral tolerization to myelin basic protein suppress both in vitro and in vivo immune response by the release of transforming growth factor $\beta$ after antigen-specific triggering. Proc. Natl. Acad. Sci. USA. 89: 421-425.

14. Chen, Y., V.K. Kuchroo, J. Inobe, D.A. Hafler, and H.L. Weiner. 1994. Regulatory $\mathrm{T}$ cell clones induced by oral tolerance: suppression of autoimmune encephalomyelitis. Science. 265:1237-1240.

15. Chen, Y., J. Inobe, and H.L. Weiner. 1995. Induction of oral tolerance to myelin basic protein in $\mathrm{CD}^{+}$-depleted mice: $\mathrm{CD} 4^{+}$and $\mathrm{CD} 8^{+}$cells mediate active suppression. J. Immunol. 155:910-916.

16. Friedman, A., and H.L. Weiner. 1994. Induction of anergy or active suppression following oral tolerance is determined by antigen dosage. Proc. Natl. Acad. Sci. USA. 91:6688-6692. 
17. Fukaura, H., S.C. Kent, M.J. Pietrusewicz, S.J. Khoury, H.L. Weiner, and D.A. Hafler. 1996. Induction of circulating myelin basic protein and proteolipid protein-specific transforming growth factor-beta 1-secreting Th3 T cells by oral administration of myelin in multiple sclerosis patients. J. Clin. Invest. 98 : $70-77$

18. Von-Herrath, M.G., T. Dyrberg, and M.B. Oldstone. 1996. Oral insulin treatment suppresses virus-induced antigen-specific destruction of beta cells and prevents autoimmune diabetes in transgenic mice. J. Clin. Invest. 98:13241331.

19. Mueller, R., T. Krahl, and N. Sarvetnick. 1996. Pancreatic expression of interleukin-4 abrogates insulitis and autoimmune diabetes in nonobese diabetes (NOD) mice. J. Exp. Med. 184:1093-1099.

20. Lee, M.-S., D. Gu, L. Feng, S. Curriden, M. Arnush, T. Krahl, D. Gurushanthaiah, C. Wilson, D.L. Loskutoff, H. Fox, and N. Sarvetnick. 1995. Accumulation of extracellular matrix and developmental dysregulation in the pancreas by transgenic production of transforming growth factor- $\beta 1$. Am. J. Pathol. 147:42-52.

21. Sanvito, F., A. Nichols, P.L. Herrera, J. Huarte, A. Wohlwend, J.D. Vassalli, and L. Orci. 1995. TGF- $\beta 1$ overexpression in murine pancreas induces chronic pancreatitis and, together with TNF- $\alpha$, triggers insulin-dependent diabetes. Biochem. Biophys. Res. Commun. 217:1279-1286.

22. Lee, M.-S., S. Stephen, M. Arnush, T. Krahl, M. von-Herrath, M.B. Oldstone, and N. Sarvetnick. 1996. Transforming growth factor- $\beta$ fails to inhibit allograft rejection or virus-induced autoimmune diabetes in transgenic mice. Transplantation. 61:1112-1113.

23. Wahl, S.M. 1992. Transforming growth factor beta (TGF- $\beta$ ) in inflammation: a cause and cure. J. Clin. Immunol. 12:61-74.

24. Brunner, A.M., H. Marquardt, A.R. Malacko, M.N. Lioubin, and A.F. Purchio. 1989. Site-directed mutagenesis of cysteine residues in the pro-region of the transforming growth factor- $\beta 1$ precursor. Expression and characterization of mutant proteins. J. Biol. Chem. 264:13660-13664.

25. Samuel, S.K., R.A.R. Hurta, P. Kondaiah, N. Khalil, E. Turley, J.A. Wright, and A.H. Greenberg. 1992. Autocrine induction of tumor protease production and invasion by a metallothionein-regulated TGF- $\beta 1$ (Ser223, 225). EMBO (Eur. Mol. Biol. Organ.) J. 11:1599-1605.

26. Moritani, M., K. Yoshimoto, F. Tashiro, C. Hashimoto, J. Miyazaki, S. Ii, E. Kudo, H. Iwahana, Y. Hayashi, T. Sano, and M. Itakura. 1994. Transgenic expression of IL-10 in pancreatic islet A cells accelerates autoimmune insulitis and diabetes in non-obese diabetic mice. Int. Immunol. 6:1927-1936.

27. Efrat, S., G. Teitelman, M. Anwar, D. Ruggiero, and D. Hanahan. 1988. Glucagon gene regulatory region directs oncoprotein expression to neurons and pancreatic $\alpha$ cells. Neuron. 1:605-613.

28. Moritani, M., K. Yoshimoto, S. Ii, M. Kondo, H. Iwahana, T. Sano, N.
Nakano, H. Kikutani, and M. Itakura. 1996. Prevention of adoptively transferred diabetes in nonobese diabetic mice with IL-10-transduced islet-specific Th1 lymphocytes. A gene therapy model for autoimmune diabetes. J. Clin. In vest. 98:1851-1859.

29. Ikeda, T., M.N. Lioubin, and H. Marquardt. 1987. Human transforming growth factor type beta 2 : production by a prostatic adenocarcinoma cell line, purification, and initial characterization. Biochemistry. 26:2406-2410.

30. Nakano, N., H. Kikutani, H. Nishimoto, and T. Kishimoto. 1991. T cell receptor $\mathrm{v}$ gene usage of islet $\beta$ cell-reactive $\mathrm{T}$ cells is not restricted in nonobese diabetic mice. J. Exp. Med. 173:1091-1097.

31. Wong, F.S., I. Vusintin, L. Wen, R.A. Flavell, and C.A. Janeway. 1993 $\mathrm{CD}^{+}$cell clones from young nonobese diabetic (NOD) islets can transfer rapid onset of diabetes in NOD mice in the absence of $\mathrm{CD}^{+}{ }^{+}$cells. J. Exp. Med. 183 : $67-76$.

32. Kopp, J.B., V.M. Factor, M. Mozes, P. Nagy, N. Sanderson, E.P. Bottinger, P.E. Klotman, and S.S. Thorgeirsson. 1996. Transgenic mice with in creased plasma levels of TGF-beta 1 develop progressive renal disease. Lab. Invest. 74:991-1003.

33. Groux, H., A. O'Garra, M. Bigler, M. Rouleux, S. Antonenko, J.E. de Vries, and M.G. Roncarolo. 1997. A CD4 ${ }^{+}$T-cell subset inhibits antigen-specific T-cell responses and prevents colitis. Nature. 389:737-742.

34. Pankewycz, O.G., J.X. Guan, and J.F. Benedict. 1992. A protective NOD islet-infiltrating $\mathrm{CD} 8^{+} \mathrm{T}$ cell clone, I.S. 2.15, has in vitro immunosuppressive properties. Eur. J. Immunol. 22:2017-2023.

35. Han, H.S., H.S. Jun, T. Utsugi, and J.W. Yoon. 1996. A new type of $\mathrm{CD}^{+}{ }^{+}$suppressor $\mathrm{T}$ cell completely prevents spontaneous autoimmune diabetes and recurrent diabetes in syngeneic islet-transplanted NOD mice. J. Autoimmun. 9:331-339.

36. Hu-Li, J., H. Huang, J. Ryan, and W.E. Paul. 1997. In differentiated $\mathrm{CD}^{+}{ }^{+} \mathrm{T}$ cells, interleukin 4 production is cytokine-autonomous, whereas interferon gamma production is cytokine-dependent. Proc. Natl. Acad. Sci. USA. 94: 3189-3194.

37. Nakamura, T., R.K. Lee, S.Y. Nam, E.R. Podack, K. Bottomly, and R.A. Flavell. 1997. Roles of IL-4 and IFN-gamma in stabilizing the T helper cell type 1 and 2 phenotype. J. Immunol. 158:2648-2653.

38. Nakamura, T., Y. Kamogawa, K. Bottomly, and R.A. Flavell. 1997. Polarization of IL-4- and IFN-gamma-producing $\mathrm{CD}^{+} \mathrm{T}$ cells following activation of naive $\mathrm{CD}^{+}{ }^{+} \mathrm{T}$ cells. J. Immunol. 158:1085-1094.

39. Shaw, M.K., J.B. Lorens, A. Dhawan, R. DalCanto, H.Y. Tse, A.B Tran, C. Bonpane, S.L. Eswaran, S. Brocke, N. Sarvetnick, et al. 1997. Local delivery of interleukin 4 by retrovirus-transduced T lymphocytes ameliorates experimental autoimmune encephalomyelitis. J. Exp. Med. 185:1711-1714. 